\title{
Capsule Contraction Syndrome with a Microincision Foldable Hydrophilic Acrylic Intraocular Lens: Two Case Reports and Review of the Literature
}

\author{
Angelo Balestrazzi Alex Malandrini Gianluca Martone \\ Davide Marigliani Tomaso Caporossi Gian Marco Tosi \\ Department of Ophthalmology, University of Siena, Siena, Italy
}

\section{Key Words}

Cataract surgery $\cdot$ Capsulorhexis $\cdot$ Capsule contraction syndrome

\begin{abstract}
Here we present 2 cases of capsule contraction syndrome (CCS). In both cases, a hydrophilic acrylic Akreos MI60 (Bausch and Lomb) intraocular lens (IOL) was implanted in the capsular bag through microincision cataract surgery, and the literature on the subject is reviewed. Since CCS has been described after the implantation of every IOL type, it is unlikely that the Akreos MI60 chemical and physical properties may cause CCS. When CCS occurs with IOLs composed of increasingly flexible materials that are inserted through incisions of decreasing size, a severe dislocation and deformation of IOL optics and haptics may develop. In both cases illustrated here, Nd:YAG laser anterior capsulotomy was highly effective. Hence, also based on the literature, which reports severe complications as a result of surgical intervention, it is suggested that Nd:YAG laser anterior capsulotomy be the first line of CCS treatment when the luxation of an IOL capsular bag is absent.

(c) 2014 S. Karger AG, Basel
\end{abstract}

\section{Introduction}

The goal of modern cataract surgery is the rapid restoration of vision, which explains the tendency towards microincision phacoemulsification. However, serious postoperative complications may occur. Capsule contraction syndrome (CCS) is a well-recognized postoperative complication of cataract surgery, which has been mainly observed in conditions of zonular weakness and chronic intraocular inflammation [1-2]. The material

Gian Marco Tosi

Department of Ophthalmology, University of Siena

Viale Bracci 1

IT-53100 Siena (Italy)

E-Mail gmtosi@tin.it 
Balestrazzi et al.: Capsule Contraction Syndrome with a Microincision Foldable

and design of intraocular lenses (IOLs) have been hypothesized to play a role in anterior capsule opacification, the milder form of the disease [2]. However, CCS has been reported to occur with different types of IOLs, including polymethylmethacrylate, silicone and acrylic [224]. Herein, we illustrate 2 cases of CCS following microincision cataract surgery without any associated ocular or systemic disease and we also review the literature on the subject (table 1).

\section{Case Reports}

Case 1

A 72-year-old female was referred to our center due to visual acuity reduction in her left eye (LE). Her general medical history was unremarkable. Her ocular history was positive for cataract surgery involving microincision phacoemulsification and an in-the-bag implantation of an Akreos MI60 (Bausch and Lomb) IOL in her LE 4 months previously. She did not report having had any ocular pathologies in the past. It was not possible to review her old records. Best-corrected visual acuity (BCVA) was 20/60 in her right eye (RE) and 20/100 in her LE. Dilated slit-lamp examination revealed a corticonuclear cataract in her RE, while her LE showed phimosis and a complete occlusion of the capsulorhexis incision by anterior capsule shrinkage, together with folding of the haptics as well as tilting and decentration of the IOL (fig. 1a, b). Her intraocular pressure was within normal limits in both eyes. A fundus examination showed normal results in both eyes, although CCS impaired her vision in the LE. No signs of past or current ocular inflammation or pseudoexfoliation were observed. Ultrabiomicroscopy analysis revealed a partial ciliary body detachment (fig. 1e, f). In her LE, a neodymium:YAG (Nd:YAG) laser was used to create a radial opening in the capsular phimosis, then to perform a circular enlargement and resolve the capsular synechiae of the haptics (fig. 1c, d). One week after Nd:YAG treatment, the visual acuity in her LE was 20/20 and the ciliary body detachment had been resolved (fig. 1g, h). Three months later, phacoemulsification and an in-the-bag implantation of an AcrySof SA60AT (Alcon) hydrophobic acrylic IOL was performed in her RE. Six months later, her BCVA was 20/20 in both eyes, without any CCS in her RE.

Case 2

A 68-year-old female was referred to our center because of a visual acuity reduction in her LE. Her general medical history was unremarkable, while her ocular history was positive for cataract surgery involving microincision phacoemulsification and an in-the-bag implantation of an Akreos MI60 (Bausch and Lomb) IOL in her LE 3 months previously. She did not report having had any ocular pathologies in her past. It was not possible to review her old records. BCVA was 20/60 in her RE and 20/30 in her LE. Her LE showed a hypermetropic refraction of $+2+0.50 \times 175$. The patient reported that her LE visual acuity had been excellent, without spectacle correction, for the first 1.5 months after surgery. Dilated slitlamp examination revealed a corticonuclear cataract in her RE and phimosis of the anterior capsule with capsulorhexis reduced to $2 \mathrm{~mm}$ in her LE, together with anterior folding of the haptics and a posterior dislocation of the IOL optic. Her intraocular pressure was within normal limits in both eyes. A fundus examination showed normal results in both eyes, although CCS impaired her vision in the LE. No signs of past or current ocular inflammation or pseudoexfoliation were observed. In her LE, an Nd:YAG laser was used to create a radial opening in the capsular phimosis, then to perform a circular enlargement and resolve the capsular synechiae of the haptics (fig. 1i). One week after Nd:YAG treatment, the visual 
Balestrazzi et al.: Capsule Contraction Syndrome with a Microincision Foldable

acuity in her LE was 20/20 without correction. Three months later, phacoemulsification and an in-the-bag implantation of an AcrySof SA60AT (Alcon) hydrophobic acrylic IOL was performed in her RE. Six months later, BCVA was 20/20 in both eyes, without any CCS in her RE.

\section{Discussion}

While most patients who have cataract surgery with posterior-chamber IOL placement have excellent long-term results, IOL-related complications may occur even when the IOL is placed in the capsular bag. CCS is a postoperative complication occurring after in-the-bag IOL placement. The degree of anterior capsule contraction is believed to be related to many predictors, including the state of the patients' lens capsules and zonules, concurrent ocular pathology, and surgical complications [1-2].

We reported 2 patients with CCS after microincision cataract surgery hydrophilic acrylic Akreos MI60 IOLs were implanted in the capsular bag, without any associated ocular or systemic diseases. Both patients developed CCS, which caused ciliary body detachment in the first patient (as reported by Lanzl [7], Salzman et al. [8], and Srinivasan et al. [10]) and posterior dislocation of the IOL optic in the latter (as reported by Sanders et al. [14], Ozturk et al. [16], Qatarneh et al. [21], and Zaugg et al. [23]) (table 1). Notwithstanding the fact that no ocular risk factors were apparently present (since surgery had been performed elsewhere), we cannot exclude a weakness of the zonular apparatus, even in the absence of pseudoexfoliation or a small capsulorhexis as intraoperative causative factors of CCS.

We do not believe that Akreos MI60 chemical properties or its plate-haptic design played a role in causing CCS. In a series of 135 eyes, Can et al. [24] compared standard coaxial, microcoaxial and biaxial microincision cataract surgery in 2010, implanting 20 Akreos MI60 IOLs without reporting any cases of CCS at the respective 3-month follow-ups.

Notwithstanding the fact that the composition and design of IOLs might also influence the degree of anterior capsule contraction, CCS has been reported to occur with different types of IOLs including PMMA, silicone and acrylic, both hydrophobic and hydrophilic [224].

The literature data shows that CCS has occurred in eyes with and without risk factors after the implantation of every IOL type (PMMA, silicone and acrylic); however, looking at the most recent reports, CCS has mainly developed after hydrophilic acrylic IOL implantation (in 1 case after implanting Akreos MI60 [18], in 1 case after Raysoft 574 R, Rayner Intraocular lenses, Ltd. [23], in 1 case after Bioacryl, Biotech [23], in 5 cases after Quatrix IOL, Croma Pharma GmbH [22], and in 6 cases after implanting an Akreos IOL lens [19-21]) (table 1).

Nd:YAG laser anterior capsulotomy was effective in clearing the visual axis in both our patients and in resolving the ciliary body detachment in the first patient and the refractive error induced by the posterior dislocation of the IOL optic in the second. In the past, numerous successes with Nd:YAG laser anterior capsulotomy have been reported without any associated complications (table 1). We believe that the first treatment should always be performed with Nd:YAG laser anterior capsulotomy, unless an evident luxation of the complex IOL capsular bag is present. In fact, as reported by Ozturk et al. [16] and by Michael et al. [22], surgical treatment may lead to severe complications, notwithstanding a wellconducted original phacoemulsification, which is mainly the result of the capsular bag removal. In these cases, the authors $[16,22]$ did not report any previous attempts of treatment with Nd:YAG laser anterior capsulotomy (table 1). 
Balestrazzi et al.: Capsule Contraction Syndrome with a Microincision Foldable Hydrophilic Acrylic Intraocular Lens: Two Case Reports and Review of the Literature

As the interest in microincision cataract surgery continues to grow, there is a tendency to find increasingly flexible materials to insert or inject through smaller incisions [16]. However, as stressed by Zaugg et al. [23], Qatarneh et al. [21] and by Caravella [20], we believe that, when CCS occurs with IOLs such as the Akreos MI60, which has to be particularly soft to enter the eye through a microincision, it easily causes compression stretching of the IOL, resulting in a significant dislocation and deformation of both the optics and the haptics.

\section{Disclosure Statement}

The authors declare no conflict of interest.

\section{References}

1 Davison JA: Capsule contraction syndrome. J Cataract Refract Surg 1993;19:582-589.

-2 Werner L, Pandey SK, Escobar-Gomez M, Visessook N, Peng Q, Apple DJ: Anterior capsule opacification; a histopathological study comparing different IOL styles. Ophthalmology 2000;107:463-471.

-3 Scorolli L, Martini E, Scalinci SZ, Scorolli LG, Meduri R: Capsule contraction after continuous curvilinear capsulorhexis. J Cataract Refract Surg 1996;22:1245-1246.

4 Hayashi K, Hayashi H, Matsuo K, Nakao F, Hayashi F: Anterior capsule contraction and intraocular lens dislocation after implant surgery in eyes with retinitis pigmentosa. Ophthalmology 1998;105:1239-1243.

5 Spang KM, Rohrbach JM, Weidle EG: Complete occlusion of the anterior capsular opening after intact capsulorhexis: clinicopathologic correlation. Am J Ophthalmol 1999;127:343-345.

-6 Chawla JS, Shaikh MH: Neodymium: Neodymium: YAG laser parabolic anterior capsulotomy in extreme capsule contraction syndrome. J Cataract Refract Surg 1999;25:1415-1417.

7 Lanzl IM, Kopp C: Ciliary body detachment caused by capsule contraction. J Cataract Refract Surg 1999;25:1412-1414.

8 Salzmann J, Khaw PT, Laidlaw A: Choroidal effusions and hypotony caused by severe anterior lens capsule contraction after cataract surgery. Am J Ophthalmol 2000;129:253-254.

-9 Sudhir RR, Rao SK: Capsulorhexis phimosis in retinitis pigmentosa despite capsular tension ring implantation. J Cataract Refract Surg 2001;27:1691-1694.

-10 Srinivasan S, van der Hoek J, Green F, Atta HR: Tractional ciliary body detachment, choroidal effusion, and hypotony caused by severe anterior lens capsule contraction following cataract surgery. Br J Ophthalmol 2001;85:1261-1262.

11 Moreno-Montañés J, Sánchez-Tocino H, Rodriguez-Conde R: Complete anterior capsule contraction after phacoemulsification with acrylic intraocular lens and endocapsular ring implantation. J Cataract Refract Surg 2002;28:717-719.

12 Ueno S, Kimura A, Hirata A, Tanihara H: Surgical treatment of complete anterior capsule contraction after cataract surgery. Acta Ophthalmol Scand 2004;82:461-462.

13 Musa F, Aralikatti AK, Prasad S: Choroidal effusion and hypotony caused by severe anterior lens capsule contraction following cataract surgery. Eur J Ophthalmol 2004;14:153-155.

14 Sanders DR, Higginbotham RW, Opatowsky IE, Confino J: Hyperopic shift in refraction associated with implantation of the single-piece Collamer intraocular lens. J Cataract Refract Surg 2006;32:2110-2112.

15 Prakash P, Kasaby HE, Aggarwal RK, Humfrey S: Microincision bimanual phacoemulsification and Thinoptx implantation through a $1.70 \mathrm{~mm}$ incision. Eye (Lond) 2007;21:177-182.

-16 Ozturk F, Snyder ME, Osher RH, Bishop JR 3rd: Hyperopic shift with posterior bowing of a Collamer posterior chamber intraocular lens. J Cataract Refract Surg 2007;33:159-161.

-17 Venkatesh R, Tan CS, Veena K, Ravindran RD: Severe anterior capsular phimosis following acrylic intraocular lens implantation in a patient with pseudoexfoliation. Ophthalmic Surg Lasers Imaging 2008;39:228-229.

-18 Cavallini GM, Masini C, Campi L, Pelloni S: Capsulorhexis phimosis after bimanual microphacoemulsification and in-the-bag implantation of the Akreos MI60 intraocular lens. J Cataract Refract Surg 2008;34:15981600.

19 Dubois VDJP, Ainsworth G, Liu CSC: Unilateral capsular phimosis with an acrylic IOL and two capsular tension rings in pseudoexfoliation. Clin Experiment Ophthalmol 2009;37:631-633.

20 Caravella LP: Laser treatment alternative to IOL exchange for capsulorhexis phimosis with anterior flexing of single-piece hydrophilic acrylic IOL haptics. J Cataract Refract Surg 2010;36:2222-2223.

21 Qatarneh D, Hau S, Tuft S: Hyperopic shift from posterior migration of hydrophilic acrylic intraocular lens optic. J Cataract Refract Surg 2010;36:161-163. 
Case Reports in

Ophthalmology
Case Rep Ophthalmol 2014;5:329-334

DOI: $10.1159 / 000368344$

Balestrazzi et al.: Capsule Contraction Syndrome with a Microincision Foldable

Hydrophilic Acrylic Intraocular Lens: Two Case Reports and Review of the Literature

22 Michael K, O'Colmain U, Vallance JH, Cormack TGM: Capsule contraction syndrome with haptic deformation and flexion. J Cataract Refract Surg 2010;36:686-689.

23 Zaugg B, Werner L, Neuhann T, Burrow M, Davis D, Mamalis N, Tetz M: Clinicopathologic correlation of capuslorhexis phimosis with anterior flexing of single-piece hydrophilic acrylic intraocular lens haptics. J Cataract Refract Surg 2010;36:1605-1609.

-24 Can I, Takmaz T, Yildiz Y, Ali Bayhan H, Soyugelen G, Bostanci B: Coaxial, microcoaxial, and biaxial microincision cataract surgery: prospective comparative study. J Cataract Refract Surg 2010;36:740-746. 
Table 1. CCS after cataract surgery

\begin{tabular}{|c|c|c|c|c|c|c|c|c|c|c|c|}
\hline Study & IOL type & $\begin{array}{l}\text { Eyes implantec } \\
\text { with } \\
\text { this IOL type, } \mathrm{n}\end{array}$ & $\begin{array}{l}\text { dEyes } \\
\text { with CCS, } \\
\text { n }\end{array}$ & $\begin{array}{l}\text { Age of } \\
\text { patients } \\
\text { with CCS, } \\
\text { years }\end{array}$ & $\begin{array}{l}\text { Predisposing } \\
\text { ocular } \\
\text { conditions }\end{array}$ & CCC size, mm & $\begin{array}{l}\text { CTR im- } \\
\text { plantation } \\
\text { at the time of } \\
\text { surgery }\end{array}$ & $\begin{array}{l}\text { Time between } \\
\text { surgery and CCS }\end{array}$ & $\begin{array}{l}\text { Clinical } \\
\text { manifestations }\end{array}$ & Treatment & Complications \\
\hline $\begin{array}{l}\text { Scorolli } \\
{[3], 1996}\end{array}$ & PMMA (NBS) & NR & 2 & 28,68 & $\mathrm{M}(1)$ & 4.5 & $\mathrm{NI}$ & 1 month & NR & $\mathrm{L}(2)$ & NR \\
\hline $\begin{array}{l}\text { Hayashi } \\
{[4], 1998}\end{array}$ & $\begin{array}{l}\text { PMMA MZ60BD } \\
\text { (Alcon) }\end{array}$ & 47 & 14 & NR & RP (47) & 5.5 & $\mathrm{NI}$ & within 12 months & VAR & L (14) & NR \\
\hline $\begin{array}{l}\text { Spang } \\
{[5], 1999}\end{array}$ & PMMA (NBS) & NR & 1 & 81 & NAG & $4-5$ & NI & 2 months & VAR & SC & NR \\
\hline $\begin{array}{l}\text { Chawla } \\
{[6], 1999}\end{array}$ & Allergan SI30 NB & NR & 1 & 80 & NR & 5 & $\mathrm{NI}$ & 1.5 months & VAR & $\mathrm{L}$ & NR \\
\hline $\begin{array}{l}\text { Lanzl } \\
{[7], 1999} \\
\end{array}$ & $\begin{array}{l}\text { 3-piece PMMA, } \\
\text { Pharmacia 155A }\end{array}$ & NR & 1 & 74 & None & 5 & $\mathrm{NI}$ & 18 months & $\begin{array}{l}\text { VAR, CBD with } \\
\text { hypotony }\end{array}$ & $\mathrm{L}$ & NR \\
\hline $\begin{array}{l}\text { Salzmann } \\
{[8], 2000}\end{array}$ & $\begin{array}{l}\text { Foldable silicone (NBS), } \\
\text { one-piece PMMA (NBS) }\end{array}$ & NR & 2 & 72,70 & OAG (2) & NR & $\mathrm{NI}$ & 2 months (2) & $\begin{array}{l}\text { VAR (2), CBD } \\
\text { with hypotony (2) }\end{array}$ & $\begin{array}{l}\mathrm{L} \text { and SC (1), } \\
\mathrm{L}(1)\end{array}$ & $\begin{array}{l}\text { L ineffective } \\
\text { in } 1\end{array}$ \\
\hline $\begin{array}{l}\text { Sudhir } \\
{[9], 2001}\end{array}$ & $\begin{array}{l}\text { PMMA, Universal } \\
\text { Model }\end{array}$ & NR & 1 & 56 & RP, zonular laxity & 6 & $\mathrm{I}$ & 4 months & & $\mathrm{L}$ & NR \\
\hline $\begin{array}{l}\text { Srinivasan } \\
{[10], 2001} \\
\end{array}$ & Allergan SI40 NB & NR & 1 & 72 & $\begin{array}{l}\text { OAG, previous } \\
\text { trabeculectomy }\end{array}$ & 5 & NI & 2.5 months & $\begin{array}{l}\text { CBD, hypotony, } \\
\text { VAR }\end{array}$ & $\mathrm{L}$ & NR \\
\hline $\begin{array}{l}\text { Montanes } \\
{[11], 2002}\end{array}$ & $\begin{array}{l}\text { AcrySof MA30BA } \\
\text { (Alcon) }\end{array}$ & NR & 2 & 69 & PXE phakodonesis & NR & I (2) & 2 months & VAR (1) & $\mathrm{L}(1)$ & NR \\
\hline $\begin{array}{l}\text { Ueno } \\
{[12], 2004}\end{array}$ & $\begin{array}{l}\text { AcrySof MA60BM } \\
\text { (Alcon) }\end{array}$ & NR & 1 & 80 & $\begin{array}{l}\text { PXE, OAG, } \\
\text { phacodonesis }\end{array}$ & $4-5$ & $\mathrm{NI}$ & 1 month & VAR & $\begin{array}{l}\text { IOLE, CBR, Vx, } \\
\text { scleral fixation IOL }\end{array}$ & NR \\
\hline $\begin{array}{l}\text { Musa } \\
{[13], 2004}\end{array}$ & $\begin{array}{l}\text { Soflex } 2 \\
\text { (Bausch and Lomb) }\end{array}$ & NR & 1 & 81 & $\begin{array}{l}\text { OAG, previous } \\
\text { trabeculectomy }\end{array}$ & 5 & $\mathrm{NI}$ & 2 months & $\begin{array}{l}\text { VAR, hypotony, } \\
\text { choroidal effusion }\end{array}$ & $\mathrm{L}$ & NR \\
\hline $\begin{array}{l}\text { Sanders } \\
{[14], 2006} \\
\end{array}$ & $\begin{array}{l}\text { Collamer CC4204BF } \\
\text { (Staar Surgical) }\end{array}$ & 160,000 & 40 & NR & NR & $\begin{array}{l}\text { Less than } 5.5 \\
\text { in several eyes }\end{array}$ & NR & 1 week, 11 months & HS (40) & L (14) & NR \\
\hline $\begin{array}{l}\text { Prakash } \\
{[15], 2007}\end{array}$ & $\begin{array}{l}\text { ThinOptX } \\
\text { (ThinOptX, Inc) }\end{array}$ & 50 & 1 & NR & NR & NR & $\mathrm{NI}$ & NR & NR & $\begin{array}{l}\text { IOLE } \\
\end{array}$ & NR \\
\hline $\begin{array}{l}\text { Ozturk } \\
{[16], 2007}\end{array}$ & $\begin{array}{l}\text { Collamer CC420BF } \\
\text { (Staar Surgical) }\end{array}$ & NR & 2 & 69,72 & None & $\begin{array}{l}4.5(1) \\
\text { NR (1) } \\
\end{array}$ & $\mathrm{NI}$ & $\begin{array}{l}1 \text { month (1), } 7 \text { weeks } \\
\text { (1) }\end{array}$ & HS (1), HS-VAR (1) & $\begin{array}{l}\text { OLEE (1), IOLE- } \\
\text { CBR-IOLAC (1) }\end{array}$ & CE in 1 \\
\hline $\begin{array}{l}\text { Venkatesh } \\
{[17], 2008}\end{array}$ & $\begin{array}{l}\text { Sensar AR40e } \\
\text { (AMO) }\end{array}$ & NR & 1 & 65 & PXE & $5-5.5$ & NI & 2 months & VAR & $\mathrm{L}$ & NR \\
\hline $\begin{array}{l}\text { Cavallini } \\
{[18], 2008}\end{array}$ & $\begin{array}{l}\text { Akreos MI60 } \\
\text { (Bausch and Lomb) }\end{array}$ & NR & 1 & 80 & None & 5 & NI & 6 months & VAR & SC & NR \\
\hline $\begin{array}{l}\text { Dubois } \\
{[19], 2009} \\
\end{array}$ & $\begin{array}{l}\text { Akreos Adapt } \\
\text { (Bausch and Lomb) }\end{array}$ & NR & 1 & 90 & PXE & 4 & $\mathrm{I}$ & 1,5 months & VAR & $\mathrm{L}$ & NR \\
\hline $\begin{array}{l}\text { Caravella } \\
{[20], 2010}\end{array}$ & $\begin{array}{l}\text { Akreos } \\
\text { (Bausch and Lomb) }\end{array}$ & $\begin{array}{l}\text { Large series } \\
\text { NBS }\end{array}$ & 2 & NR & None & 5.5 & NI & 3 months (1), NR (1) & none & $\mathrm{L}$ & NR \\
\hline $\begin{array}{l}\text { Qatarneh } \\
{[21], 2010} \\
\end{array}$ & $\begin{array}{l}\text { Akreos Adapt } \\
\text { (Bausch and Lomb) }\end{array}$ & NR & 3 & $\begin{array}{l}55,48, \\
59 \\
\end{array}$ & M (2), RP (2) & NR & $\mathrm{NI}$ & $\begin{array}{l}9 \text { months, } 11 \text { months, } \\
6 \text { months }\end{array}$ & $\operatorname{HS}(2), \operatorname{VAR}(1)$ & $\begin{array}{l}\text { no (1), L (1), } \\
\text { SC (1) }\end{array}$ & $\begin{array}{l}\mathrm{L}(1) \text { and SC (1) } \\
\text { not effective }\end{array}$ \\
\hline $\begin{array}{l}\text { Michael } \\
{[22], 2010}\end{array}$ & $\begin{array}{l}\text { Quatrix } \\
\text { (Croma-Pharma GmbH) }\end{array}$ & NR & 5 & $\begin{array}{l}56,46, \\
81,84\end{array}$ & $\mathrm{RP}(1), \mathrm{U}(1)$ & $\begin{array}{l}6-8 \\
\text { NBS }\end{array}$ & NI & $\begin{array}{l}2 \text { months (1), } 2 \text { weeks } \\
(1), \\
1.5 \text { months (1), } 3 \\
\text { months (1), } \\
6 \mathrm{~m} \mathrm{(1)} \\
\end{array}$ & S VAR (5) & $\begin{array}{l}\text { IOLE-IOLAC (1), } \\
\text { SC-IOLE-CBRVx- } \\
\text { IOLAC (2), no (2) }\end{array}$ & GRT (1) \\
\hline $\begin{array}{l}\text { Zaugg } \\
{[23], 2010}\end{array}$ & $\begin{array}{l}\text { Raysoft (Rayner } \\
\text { Intraocular Lenses, Ltd), } \\
\text { Bioacryl (Biotech) } \\
\end{array}$ & $\mathrm{NR}$ & 2 & 60, NR (1) & None (1), PXE (1) & $\mathrm{NR}$ & $\begin{array}{l}\text { NI (1) } \\
\text { I (1) }\end{array}$ & 1 month (1), NR (1) & $\begin{array}{l}\text { VAR-HS (1), } \\
\text { VAR (1) }\end{array}$ & $\begin{array}{l}\text { IOLE-CBR- } \\
\text { Vx-IOLIF (1), } \\
\text { IOLE-CBR (1) } \\
\end{array}$ & NR \\
\hline $\begin{array}{l}\text { Present } \\
\text { report }\end{array}$ & $\begin{array}{l}\text { Akreos MI60 } \\
\text { (Bausch and Lomb) }\end{array}$ & NR & 2 & 72,68 & None & NR & NI & 4 months, 3 months & $\begin{array}{l}\text { VAR (2), CBD (1), } \\
\text { HS (1) }\end{array}$ & $\mathrm{L}(2)$ & NR \\
\hline
\end{tabular}

$\mathrm{CBD}=$ Ciliary body detachment; $\mathrm{CBR}=$ capsular bag removal; $\mathrm{CCC}$ = continuous curvilinear capsulorhexis; $\mathrm{CE}$ = corneal edema; $\mathrm{CTR}=$ capsular tension ring; $\mathrm{GRT}$ = giant retinal tear; $\mathrm{HS}$ = hyperopic shift; $\mathrm{I}=$ implanted OLAC IOL = in anterior chamber; IOLE IOL = exchange; IOLIF = iris-fixated IOL; L Nd:YAG = laser anterior capsulotomy; $M=$ myopia; NAG = narrow angle glaucoma; NBS = not better specified; NED = no evidence of diseas $\mathrm{NI}=$ not implanted; $\mathrm{NR}=$ not reported; $\mathrm{OAG}=$ open-angle glaucoma; $\mathrm{PXE}=$ pseudoexfoliation; $\mathrm{RP}=$ retinitis pigmentosa; $\mathrm{SC}=$ surgical anterior capsulotomy; $\mathrm{U}=\mathrm{uveitis} ; \mathrm{VAR}=\mathrm{visual}$ acuity reduction; $\mathrm{VX}=$ vitrectomy 


\section{Case Reports in \\ Ophthalmology}

\begin{tabular}{l|l}
\hline Case Rep Ophthalmol 2014;5:329-334 \\
\hline DOI: 10.1159/000368344 & $\begin{array}{l}\text { @ 2014 S. Karger AG, Basel } \\
\text { www.karger.com/cop }\end{array}$ \\
\hline
\end{tabular}

Balestrazzi et al.: Capsule Contraction Syndrome with a Microincision Foldable Hydrophilic Acrylic Intraocular Lens: Two Case Reports and Review of the Literature

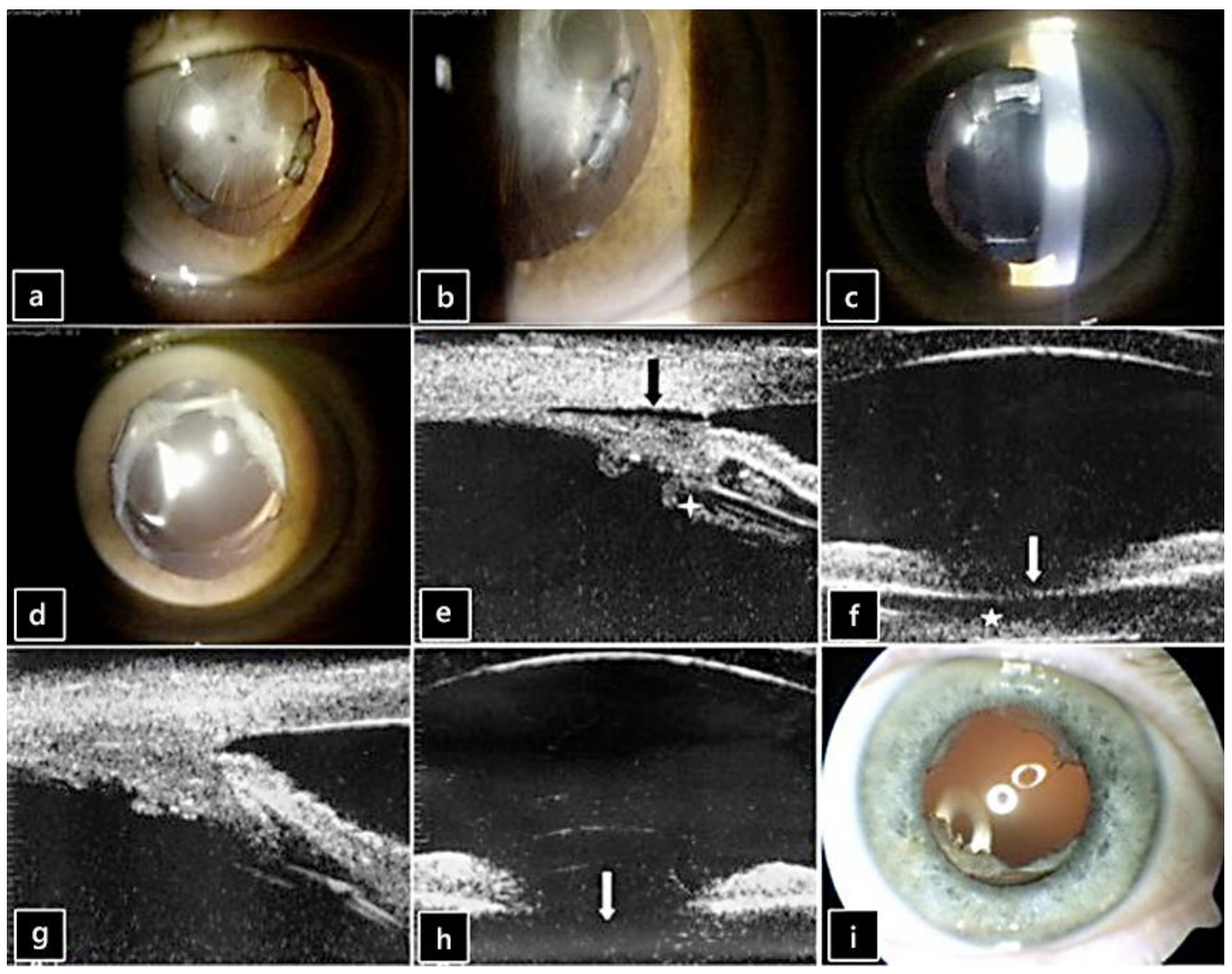

Fig. 1. a, b CCS syndrome with severe IOL deformation and dislocation. c, d Anterior segment after Nd:YAG laser treatment of the phimosis. e Preoperative ultrabiomicroscopy analysis showing a partial ciliary body detachment (black arrow) and stretched and thickened zonular fibers (white cross). f Preoperative ultrabiomicroscopy showing a capsulorhexis phimosis as a highly reflective line in the pupillary space (white arrow) and a subcapsular fibrosis as not homogeneous echoes inside the capsular bag (white star). g Ultrabiomicroscopy analysis after Nd:YAG laser treatment of the phimosis showing a resolution of the ciliary body detachment and of the zonular traction. $\mathbf{h}$ Ultrabiomicroscopy analysis after Nd:YAG laser treatment of the phimosis showing the disappearance of the high reflective line together with a deepening of the posterior chamber (white arrow). i Anterior segment after Nd:YAG laser treatment of the phimosis. 